FILOZOFIA

Roč. 75,2020 , č. 7

DOI: https://doi.org/10.31577/filozofia.2020.75.7.5

\title{
K FILOZOFICKO-EKONOMICKÝM VÝCHODISKÁM SOCIÁLNYCH LUUDSKYCH PRÁV U KARLA POLANYIHO A ERNSTA TUGENDHATA
}

MARTIN MURÁNSKY, Filozofický ústav Slovenskej akadémie vied, Bratislava, SR

MURÁNSKY, M.: On Philosophical-Economic Starting Points of Social Human Rights in Karl Polanyi and Ernst Tugendhat

FILOZOFIA, 75, 2020, No 7, pp. $569-583$

\begin{abstract}
The key theses of the study emphasizes the finiteness of meaning in contrast to economic determinism as normative starting point of K. Polanyi's and E. Tugendhat's vision of democratic society, controlled by its citizens. This egalitarian point of departure of defence of social human rights is at the same time the answer to their common dilemma, hidden in conflicting relationship of primacy of right to own to right to life. Taking into account Tugendhat's critique of libertarian concept of "free" social contract as the will to power in connection with Polanyi's unmasking of automaton of libertarian spontaneous equilibrium as political construct and selfdestructing illusion, the study shows that the drop out of social rights in this concept is based on the nominalistic grasp of reality, in relation to which any form of collective self-determination seems to be the enemy of freedom. The second presupossition of this drop out is to be found in the libertarian idea of the natural order of free market connected with the ideal of negative freedom and trickle down economy, based on the illusion of reality consisting of unlimited resources and the cooperation of already self-sufficient, healthy and adult owners of the sources of subsistance.
\end{abstract}

Keywords: Finiteness of meaning - Collective self-determination - Nominalism Illusion of natural marked order - Right to work

Ciel'om štúdie je tematizácia normatívnych predpokladov dvoch základných a navzájom sa vylučujúcich konceptov slobody vo vzt’ahu k problematike sociálnych a ekonomických práv. Základným prostriedkom naplnenia tohto ciel’a je nami stanovená téza o konečnosti zmyslu slobody, umožňujúca porovnanie ekonomickej a filozofickej antropológie Karla Polanyiho a Ernsta Tugendhata ako východiska ich spoločnej kritiky libertarianizmu.

Aj ked' Polanyi a Tugendhat patria k odlišným generáciám myslitel’ov, obaja pokladajú vzt’ah demokracie a ekonomiky za rozhodujúci problém, skrytý v agende l’udských práv. Prvým dôvodom nášho porovnania je im vlastná tematizácia konfliktného 
vzt’ahu medzi ,právom vlastnit"“ a ,právom na život"“. Kým Tugendhat tento konflikt explicitne analyzuje (Tugendhat 1993, 310 - 336), Polanyi, píšuci zväčša pred uverejnením Všeobecnej deklarácie l’udských práv, hovorí o konflikte „práva na život“ so „slobodou podnikania“ (Polanyi 1944, 254). No na tomto pozadí rozvíjajúceho sa vzt’ahu ekonomickej moci so spoločenskou slobodou ho chápe tiež ako základné ihrisko. Druhým dôvodom, a súčasne možnostou ich porovnávania, je ich zásadná kritika a vymedzovanie sa proti libertariánskemu konceptu samovol’ne sa regulujúceho trhu a z neho vyplývajúcej redukcie slobody na jej negatívnu podobu, ktorú rozpracovali Ludwig Mises, Friedrich Hayek a pre Tugendhata osobitne dôležitý Isaiah Berlin.

Tretím je vlastná motivácia. Tá je založená na úsilí tematizovat' tugendhatovsky povedané „horizont zmyslu“ tak, že naliehavost' sociálnych a ekonomických práv vyplynie z možnosti pochopenia dôvodov ich negácie. ${ }^{1}$

\section{Vedomie konečnosti}

Úvod k filozofickému prieniku oboch kritických myslitel'ov predstavuje Polanyiho charakteristika základnej črty západnej civilizácie konečnosti vedomia človeka (Polanyi 1944, 256). Nachádza ju vo „vedomí smrti, vedomí slobody a vedomí spoločnosti“(tamže). Kým pri prvých dvoch charakteristikách „individualizácie človeka“ vychádza z krest’anskej tradície egalitárneho práva na spásu pre každého človeka u Maxa Webera, v prípade tej tretej, ,vedomia spoločnosti“, sa Polanyi odvoláva na preňho špecifickú a pre sled našich úvah základnú dejinnú realitu: „života v priemyselnej spoločnosti““ (tamže). Vo vzt’ahu k tejto realite priemyselnej civilizácie treba podl'a Polanyiho nanovo zadefinovat' to, čo nazýva „zmysel slobody“ (tamže, 254).

$\mathrm{Na}$ tejto otvorenosti otázky zmyslu slobody a konečnosti človeka sa zakladá aj Tugendhatov filozofický projekt. Vo svojom texte „O smrti“ (1996) formuluje leitmotív konečnosti takto: „Život nie je dobro, ale môže čiastočne vd’aka št’astným okolnostiam, čiastočne vždy aj vd’aka nám, nadobudnút' zmysel, môže, no nemusí“ (Tugendhat 2001, 81). To, čo vyzerá byt' u Tugendhata vysoko abstraktnou agendou zmyslu života, ktorý sa môže aj stratit', lebo žiadna večná istota za ním nie je - rozmieňa účastník prvej svetovej vojny Karl Polanyi na sémanticky drobné mince. Vojnový invalid Polanyi zažíva natvrdo otras dejinného normatívu osvietencov. Paradoxom slobody sa stáva jej deštruktívna možnost' zničit' základy civilizácie a života l'udstva. Vo svojom článku Poslanie jednej generácie. Na margo tejto katastrofy uvá-

\footnotetext{
${ }^{1}$ Konkrétne zdôvodnenia l'udských práv, u Polanyiho pragmatickou cestou a Tugendhata zas jeho morálnym konceptom úcty, nie sú preto súčast'ou predkladanej štúdie. Ku kritike konceptu zdôvodnenia u Tugendhata pozri A. Pollmann (2012, 427 - 428), S. Gosepath (1998, 234 - 235), Ch. Menske (2012, 170 - 177); ku kritike Polanyiho konceptu G. M. Hodgson (2016), S. C. Humphreys (2017).
} 
dza: „Utrpenie bolo utrpením duše, ktorej existencia stratila zmysel. Človek však nevie žit' vo svete, v ktorom by bola márna snaha hl'adat' jeho zmysel...“ (Polanyi 1918, 23).

Podl'a ekonomického antropológa s podrobnou znalost'ou Radostnej vedy nielenže vo svete, ktorý stratil zmysel, nevieme žit', ale ho nedokážeme ,ani len adekvátne opísat"“ (tamže). Odpoved'ou na tento výpadok pochopenia zmyslu doby a existencie v nej je Polanyiho majstrovské dielo Velká transformácia. O politických a sociálnych koreňoch našich čias, ktoré vyšlo v tom istom roku (1944) ako Hayekova Cesta do otroctva a zahŕňalo tak aj vysvetlenie ich historických katastrof (Polanyi, Levitt 1990, 34).

Východiskom z krízy civilizačného zmyslu sa podl’a Polanyiho má stat',znovuzrodenie“"vnútorného poznania : , [...] svet, ktorý prišiel o všetko, si výmenou zachoval len jedno: nové odhalenie [...] To, čo sme cítili, nebola potreba pripísat’ niekomu vinu za túto vojnu. Ale to, že sme všetci boli za ňu zodpovední“ (Polanyi 1918, 19). Ako však môžu byt' všetci (kolektívne) zodpovední za vojnu, ktorú nespôsobil jednotlivec? Za touto otázkou sa skrýva aj iný zásadný problém egalitárne sa rozumejúceho spoločenstva - pre Polanyiho a Tugendhata podmienky možnosti uplatnenia sociálnych práv.

Prevzatím kolektívnej zodpovednosti za vznik prvej svetovej vojny Polanyi uznáva možnost', ${ }^{2}$ že táto prelomová skúsenost' s civilizačným sebazničením sa mohla aj nestat', alebo sa udiat' ináč. Takáto otvorenost' dejinnej situácie ako uznanie konečnosti dejinného zmyslu súčasne znamená výpadok „vyššieho a priori“ ako základného motívu osamotenia „'udstva v dejinách“, ktoré musí vediet' na základe vlastných možností konania vysvetlit' dejinnú realitu miliónov obetí „strojového zabíjania“ a vzhl'adom na vlastné možnosti konania rozvrhnút humánnejší koncept dejinnej budúcnosti. Predpokladom toho je kritické myslenie, ktoré sa zodpovedne deje len v prvej osobe singuláru. Tugendhatov výklad konečnosti $\S 125$ Nietzscheho Radostnej vedy je tiež o prevzatí zodpovednosti za dejinnú situáciu. V ňom sa „smrt'ou boha“ ohlasuje koniec moci „vel'kého a priori“ v dejinách - odmietnutím delegovania vlastných možností konania na externú nespochybnitel'nú autoritu. Podl'a Tugendhata „smrt’ou boha“ sa končí aj tradičná politická morálka ako pomyselná éra univerzalizmu stavovského stredovekého štátu, ktorého moc sa opierala o metafyzicky „vy̌šši“ pôvod krvi a „darov“" z milosti. Aké civilizačné alternatívy sú $\mathrm{k}$ dispozícii?

Vzhl'adom na ne je rozhodujúce Tugendhatovo poukázanie na dvojznačnost' termínu „vôle k moci“ ako Nietzscheho odpovede na „prehodnocovanie všetkých hodnôt"“ (Tugendhat 2010, 16 - 17). ${ }^{3} \mathrm{~V}$ prvom význame predstavuje ,moc nad vôl'ami ostatných“, v druhom sa týka „moci nad sebou samým“ vo význame sebaovládania, ale tiež

\footnotetext{
${ }^{2} \mathrm{~K}$ intersubjektívnej zodpovednosti pozri Smreková (2010, 893 - 906).

${ }^{3} \mathrm{O}$ tom istom v Tugendhat v texte Hitler a Nietzsche. Slovo, 14. 11. 2000. Prel. M. Muránsky.
} 
sebaurčenia (tamže, 16). Tento kantovsky znejúci protiklad heteronómie a autonómie $\mathrm{v}$ pochopení možností vlastného konania je leitmotívom Polanyiho vymedzovania normatívnych východísk moderny v spore egalitarizmu s antiegalitarizmom - aj podla Tugendhata dvoch principiálnych alternatív vývoja modernej spoločnosti.

Polanyi vo svojom texte Podstata fašizmu analyzuje problém egalitarizmu v kontexte s touto krajnou podobou antiegalitarizmu. Základnou črtou filozofie fašizmu je podl’a Polanyiho antindividualizmus. Pre rakúskeho fašistického ideológa Othmara Spanna, ktorého kritiku izolovaného individualizmu si berie Polanyi na mušku, rozhodujúcim nie je egalitaristický ideál slobody, ale spôsob a priestor jeho realizovania. Ten vzniká podla Spanna ,prenosom individualistických doktrín o prirodzených l'udských právach z politickej sféry do ekonomickej“ (Polanyi 1979, 95). Fašizmus vo vlastnom sebapochopení má zabránit’ práve „socializmu“, a dnes by sme povedali prieniku agendy sociálnych l’udských práv do ekonomickej sféry. Polanyi na tomto mieste upozorňuje na dvojznačnost' termínu individualizmus v identickom kontexte ako Tugendhatov problém s dvojznačnost'ou termínu vôl'a k moci.

Odkazom na postavy „titanských nadl'udí“ v Dostojevského románoch (Raskol'nikov, Stavrogin, Smerd’akov), ale osobitne na Kirillova z románu Besy, Polanyi správne upozorňuje na to, že fašistická kritika atomizovaného individualizmu ako kritika konceptu slobody vôbec míňa svoj ciel’. „Titanské indivíduum“ je vyjadrením bezmedznej vôle ovládat' iných, ktorá je vlastná práve princípu fašistického vodcu. Voči tomuto ,individualizmu nerovnosti“ kladie Polanyi ,individualizmus rovnosti“, ktorý je založený na „bezpodmienečnej hodnote“ l'udského života. Takáto hodnota nefunguje izolovane, pretože implikuje hodnoty bratstva, čiže solidarity. Klúčcová veta pre náš výklad znie: „Toto učenie o bratstve implikuje, že osobnost' mimo spoločenstva nie je reálna. Realita spoločenstva spočíva vo vzt’ahu medzi osobami“" (Polanyi 1979, 101). Je to práve tento Polanyim zvýznamnený egalitaristický, a súčasne kolektívny rozmer $d e$ jinne sa rozumejúceho spoločenstva, ktorý umožňuje Tugendhatovi urobit' východiskom antropológie paradoxne singulárne znejúcu otázku - „Kto je človek? “ No táto sebareflexia, na rozdiel od ,anglosaskej tradície“, sa netýka ,jednotlivého indivídua, ale nás“, čiže spôsobu, ,ako sa chceme chápat' vcelku“ (Tugendhat 2010, 18).

Táto požiadavka sebareflexie vlastnej dejinnej situácie predpokladá rešpektovanie a uznanie individuálnej slobody. Lebo bez nej sa musí javit’ každý nárok na kritické - zodpovedné - myslenie ako obsolentný a sám osebe zbytočný. Na druhej strane je v tomto primáte chápania zahrnutá otvorenost' tejto situácie, teda odmietnutie každého deterministického automatizmu, ktorý Polanyi vidí v idei vol'ného trhu s odkazom na nadosobne fungujúci princíp ponuky a dopytu. Tugendhat vie pomôct' vysvetlit' tento primát holisticky intersubjektívneho rozumenia odkazom na leitmotív 
svoje filozofie - ,ideu kritickej zodpovednosti za pravdu“ z roku 1966, ktorým odkazuje na Husserla a jeho pojem „sveta“.

S fenomenologickým primátom ,sveta“ kultúrnych praktík v konštitúcii každého sebavedomia súvisí ich „,zabudnutost“" $v$ každodennosti a súčasne možnost' ich odkrytia (po dejinných otrasoch) ako mnou samým prevzatých a praktizovaných možností. V tomto zmysle, hoci aktérom prevzatia zodpovednosti môže byt' len, ,jednotlivý subjekt“, tvrdí Husserl ,vždy ide o ,zodpovednost' za spoločenstvo. Každý je za každého a za každé rozhodnutie a konanie iného, hoci v rozličnej miere, spoluzodpovedný“ (Husserl 1927, 152). To, čo predtým platilo pre mňa ako samozrejmý normatív spoločenstva, stráca anonymitu - ,jeho pravda“ ako kolektívne sebapochopenie, sa stáva sférou činov a rozhodnutí človeka.

\section{Ekonomický nominalizmus}

Tento konflikt o povahe slobody a reality sociálneho sveta je metodicky uznaným sporom „realizmu“ a „,nominalizmu“ aj u oponentov. ${ }^{4}$ Locus classicus predstavuje slávna, hoci nielen podla Tugendhata problematická, esej Isaiaha Berlina $O$ dvoch pojmoch slobody. Berlin v nej vychádza tiež zo ,zjavnej ambivalencie slova sloboda (Berlin 1958, 89), ked’že v tomto výraze sa skrýva prítomnost' „dvoch nezlučitel'ných postojov k životným ciel’om“ (tamže, 93) - „negatívnej“ a „pozitívnej“ slobody. Tugendhat v inom kontexte upozornil na nesprávne interpretovaný význam negatívnej slobody u Berlina ako „slobody vol'by“ (porov. Muránsky 2019). Pre náš výklad je dôležitý aj iný poukaz: Berlinovo eklektické zdôraznenie princípu vol’by ako pokusu o vysvetlenie základnej otázky doby: katastroficky narastajúceho výskytu neslobody po prvej svetovej vojne. Podla Berlina na vine je „pozitívne“ chápanie slobody človeka, definované pomocou Kantovho termínu autonómie ako „moci nad sebou“, no interpretovanej Berlinom najprv znejasňujúcim spôsobom: „som sám sebe pánom“ (tamže, 66).

V tomto vymedzení sa skrýva pre celú esej zásadné konštatovanie „metafyzického jadra racionalizmu“ $v$ dielach Kanta, Hegla alebo Marxa. To, čo z nich robí esenciálne homogénnych filozofov totality, je totiž obsiahnuté v dvojakej kantovskej optike ,vyššieho“ rozumového ,ja“, ktoré tým, že transcenduje „nižšie“ empirické ,ja“, sa stáva súčastou vyššieho celku. Tento „vyšší celok“ je podl’a Berlina utopickým príslubom „konečného riešenia“ l'udskej otázky ako inteligibilne dokonalej slobody. Berlin sa nemýli v tom, že Kant naozaj koncipuje projekt egalitárneho ,spoločenstva všetkých rozumných bytostí a ako racionálne nevyhnutný koncept, a že tento inteligibilný svet, ako všetkým empirickým ,ja“ nadradená autorita rozumu, bol zdrojom mnohých, aj dejinných omylov.

\footnotetext{
${ }^{4}$ Porov. S. C. Humphreys $(1979,11-12)$.
} 
Základným problémom Berlinovej interpretácie je podobne fundamentálny predpoklad redukcie každej formy kolektívneho sebaurčovania na nepriatela slobody. Za odkazom na metafyzickú nevyhnutnost' v Kantovom termíne autonómie Berlin vidí popretie slobody vol'by na pozadí podstatne širšieho dôvodu. Ten naplno odkryje až v poslednej časti svojej eseje (Jedno a mnohé). V nej nestojí „pozitívna sloboda“ na individuálnej autonómii, ale „objavuje sa $\mathrm{v}$ jadre požiadaviek na národné a spoločenské určovanie seba samého“ (tamže, 87). Podl’a Berlina „prirodzene“ existujú len singulárni - vo vlastnom záujme konajúci jednotlivci s „bolestivým privilégiom [individuálnej] vol'by““ (tamže, 87), vo vzt'ahu ku ktorej je každá kolektívne sa sebaurčujúca vôl'a cestou k tyranii.

K libertariánskemu normatívu oddelenia vol’ného trhu od zvyšku spoločnosti potom konzekventne patrí aj predstava o vrodenej slabosti l'udí v súvislosti s ich túžbou ovládat' iných, ktorej chcel utopický projekt racionálneho ideálneho spoločenstva zabránit'. Tejto kalvínsky hriech dedičnej slabosti človeka má zabránit' prirodzene (rozumej nadosobne) fungujúci automat regulácie cien tovarov a služieb. V každom prípade tento libertariánsky zákaz regulativov l’udského konania vo sfére trhovej ekonomiky znamená súčasne výpadok každej možnosti „pozitívnej slobody“v tomto koncepte.

\section{„Nezávislost' pracujúceho človeka“"}

$\mathrm{Na}$ inom mieste sme už poukázali na Tugendhatovu vyčerpávajúcu kritiku negatívnej slobody ako „vol'by“ jeho odkazom na kl'účovú Hayekovu metaforu horolezca (porov. Muránsky 2019a). Ten, aj ked’ má len jednu cestu na vrchol, je rovnako slobodný, ako ked' spadne do rokliny a nevie sa z nej už dostat' spät. Dôvodom slobody bez možnosti vol'by je nepritomnost'osobného prinútenia, ktorá podl'a Hayeka robí z každého jednotlivca slobodnú bytost' $v$ jeho (sociálnych) výstupoch na vrchol a jeho pádoch dolu. Differentia specifica libertariánskej vízie slobody a neslobody teda tkvie v redukcii tejto otázky slobody na osobné vzt’ahy - „vzt'ah l’udí k iným l’udom“.

Vo svojom pozitívnom koncepte Tugendhat poukáže na zásadne iný zdroj neslobody, založený na neosobnej ekonomickej moci. O neslobodnom konaní možno hovorit' nielen v prípade jeho nanútenia inými, ale aj ked’ „prakticky nemáme na výber“. To je však opačný význam „vol’by“ ako libertariánsky „ideál zodpovednosti““. 5 "Nemat' na výber“" znamená nemat' spoločnost’ou garantované sociálne dostupné príležitosti uplatnit' sa, ani sociálne nadobudnuté zručnosti, a teda ani autonómny nárok na určovanie života podl'a vlastných predstáv pre každého, primárne sociálne znevýhodneného človeka. $\mathrm{V}$ tomto zmysle Tugendhat požaduje, aby sa agenda ekonomických a sociálnych práv stala súčast’ou ,politickej morálky“, čiže legitimácie moderného demokratického štátu (porov. Tugendhat 1993, 350). Ústredným termínom je tu „l'udská

${ }^{5}$ K tomu bližšie Sedová $(2018,323-317)$. 
dôstojnost'“, ale pochopená najprv nezávisle od jej zdôvodnenia z hl'adiska realizovatel'nosti tejto autonómie.

Polanyi zdiela podobne autonómnu ,predstavu nezávislého pracujúceho človeka" v konfrontácii s neosobnou povahou ekonomickej neslobody. Polanyi demonštruje tento reálny konflikt dvoma aj dnes aktuálnymi a navzájom sa vylučujúcimi ochrannými opatreniami anglickej vlády pred novodobým rozšírením bezdomovectva a chudoby ako „vedl'ajšieho dôsledku“ zrušenia Zákona o bývaní ako podmienky vzniku národného trhu práce. Podl’a Polanyiho „sebaúctu“ pracujúceho človeka historicky degradoval „demoralizujúci Speedhamlandský zákon“ (1795) - predchodca dnešných návrhov o základnom príjme. Toto zabezpečovanie „práva na život“ (Polanyi 1944, 82) v podobe „systému dávok“ pre každého pracujúceho alebo nepracujúceho chudobného bol v realite „skutočne škodlivým princípom“ (tamže), pretože sa stal nástrojom „znižovania mzdy pre zamestnávatel'ov“ (tamže, 83). Súčasne ako lacná dávka umožňoval masám preživat' na najnižšej kultúrnej úrovni, až „sebaúcta človeka klesla k takému nízkemu bodu, že dal prednost' podpore pred mzdou“" (tamže, 82).

Jedinou alternatívou k Speedhamlandskému zákonu bol podla Polanyiho Whitbreadov návrh zákona v tom istom roku, ktorý zahrňoval „každoročne ustanovované pevné mzdové minimum“ (tamže, 284) - a určoval tak cenu práce mimo vol'ného trhu. Dôvod, prečo sa Speedhamlandský zákon presadil, vyjadruje výrok jeho predkladatel’a: „Práca, ako všetko ostatné prinášané na trh, musí vo všetkých dobách nájst' svoju úroveň bez zákonnej intervencie“ (tamže, 285). Predpokladom Polanyiho sugestívnej konfrontácie oboch legislativnych návrhov je výpadok „,práva na prácu“ vo Speedhamlandskom zákone o základnom príjme. Práve toto právo na prácu navrhne Polanyi v roku 1944 zaradit' do katalógu l'udských práv. ${ }^{6}$ To, že nešlo o žiaden idealistický návrh, dokazuje aj výsledok zmeny spoločenskej zmluvy vo vojnovej ekonomike v Británii, v rámci ktorej Lord Beverdige ako spolutvorca konceptu povojnového štátu vyjadruje jej nový zmysel v knihe Plná zamestnanost' a slobodná spoločnost' (1944). No nie odkaz na plnú zamestnanost', ale poukázanie na primát dejinnosti v pochopení aj ekonomických vzt'ahov je v tomto kontexte rozhodujúce. ${ }^{7}$ Ním sa popri nominalistickom uchopení spoločenskej reality artikuluje druhý základný normatívny predpoklad libertianizmu, téza o prirodzenej a spontánne fungujúcej rovnováhe volného trhu.

\footnotetext{
${ }^{6}$ „K listine základných práv sa musia pridat’ práva občanov, ktoré ešte nepoznáme... V čele ich výpočtu musí byt' právo na prácu“ (Polanyi 1944, 253 - 254).

${ }^{7} \mathrm{~K}$ tejto zásadnej zmene normatívu porovnaj: Mises (1927) navrhol zhrnút' libertariánsky program do jediného slova vlastníctvo, to znamená osobitné vlastníctvo výrobných prostriedkov (Mises 1927, 18). Mier a sloboda majú z neho automaticky vyplynút'. Beveridge (1944), ako upozornila Karin Levitt, Polaniyho dcéra, argumentuje nedobrovolnou nezamestnanost'ou ako zlom: jeho potláčaniu treba podriadit', ako d’alej cituje z jeho práce, aj ,právo vlastnit' výrobné prostriedky... [ktoré] nie je základnou občianskou slobodou, pretože nikdy nebolo užívané inou než vel'mi malou čast’ou britských občanov“ (Levitt Polanyi 1990, 93).
} 


\section{Prirodzený poriadok}

Tento termín znamená v tomto vymedzení pôvodnejší a vo vzt’ahu k vedomým aktivitám človeka od nich nezávislý princíp. Bol to Adam Smith, ktorý odmietol chápat' ideu vol'ného trhu ako produkt l'udského konania a namiesto toho pokladal trhovo organizovanú kooperáciu za prirodzený dôsledok, nie však výsledok l’udského zámeru, ktorý vyplýva z prirodzeného sklonu indivíduí k obchodovaniu a vzájomnej výmene vecí (porov. Polanyi 1979, 177 - 179 a 1944, 247). Ústrednou tézou Polanyiho je spochybnenie základnej predstavy libertariánskej „,spoločenskej filozofie“, totiž že „laissez-faire vznikol prirodzeným vývojom, zatial' čo následná legislatíva proti laissez-faire bola výsledkom úmyselného konania zo strany odporcov liberálneho princípu“ (Polanyi 1944, 143).

Proti tejto aj dnes praktizovanej schéme protikladu prirodzenej slobody, garantovanej vol’ným trhom, ako d’alej uvádza Polányi, voči nepriatel'skej „kolektivistickej“ legislatíve štátu sa obracia jeho téza o ekonomike vol'ného trhu ako „výsledku zámernej činnosti štátu“ (tamže, 142). Nový ekonomický poriadok, založený na systematickom zväčšovaní trhového priestoru premenou tradičných lokálnych trhov na jednotný národný, a predovšetkým globálny trhový poriadok, nielenže neboli výsledkom spontánneho vývoja, ale nové inštitucionálne zabezpečenie takzvaného „vol’ného trhu“ znamenalo ohromný nárast ustavičného, centrálne organizovaného byrokratického aparátu. Tu je Polanyiho opis vzniku osudovej moci byrokracie, verný svojmu sociologickému učitel’ovi Maxovi Weberovi (porov. Polanyi 1944, 132). Pri analýze už spomenutého Speehmlandeského zákona Polanyi upozorn̆uje aj na foucaltovský rozmer, totiž že s výskytom novej asociálne pôsobiacej masovej nezamestnanosti a chudoby je tento nárast byrokratického aparátu podmienený zvýšenou represívnou potrebou ,dozerat' a trestat'“.

Na konfliktne založenom vzt'ahu ,práva vlastnit“ $s$, ,právom na život“ je postavená Polanyiho téza „o dvojitom pohybe“ ako protinávrhu k „prirodzenému poriadku“ trhu. Podl'a tejto tézy sebaregulujúce trhy nikdy nefungovali, a to nielen z hl'adiska ich internej krízovosti, ale tiež z hl'adiska ich enormných sociálnych nákladov. Polanyi preto nazýva ideu vol’ného trhu „fikciou“ (tamže, 9), ktorá v „realite“ prináša so sebou nevyhnutnost' nových obranných intervencií zo strany spoločnosti a štátu. Ak vznik vol'ného trhu neprebehol spontánne, obranný protipohyb spoločnosti - „reštrikcie laissez-faire“ - nimi už boli, a to v rozmanitej podobe. Patria k nim historicky vybojované l'udské práva na zakladanie odborových organizácí spolu s právom na štrajk. No tiež z opačnej strany, zo strany domáceho biznisu išlo o proklamované právo na kartel a iné protekcionistické opatrenia, najmä v situáciách „strachu z neurčitej budúcnosti“" v čase kríz. 
K tomuto „protipohybu“ spoločnosti muselo dôjst', pretože vol'ný trh podl'a Polanyiho v princípe fungovat' nemôže: zakladá sa na komodifikácii všetkých vzt’ahov na trhu vrátane „pôdy, práce a peňazi“. Tie však, ako „fiktívne komodity“, nie sú tovarom určeným na predaj so ziskom (porov. Polanyi 1944, 72 - 80). Pôda ako súčast' životného prostredia nebola čírym tovarom - ani pred environmentálnou krízou. „Peniaze“, podl'a významného ekonóma J. Stiglitza, autora predslovu k Velkej transformácii v roku 2001, nimi nie sú tiež, ved' o regulácii finančných trhov sa už vtedy nepochybovalo, len sa presne nevedelo, ,akým spôsobom ju urobit"“ (Stiglitz 2001, 7).

V kontexte sociálnych práv je napokon špecifikom nepredanej práce ako tovaru fakt, že jej nositel' sa nedá niekam uskladnit' ani odpratat'. To, čo z nepredanej práce pre spoločnost' zostáva, je starost' o živobytie jej nositel'a a vice versa. No a v prípade masovej nezamestnanosti sa možno len fiktívne vyhnút' uznaniu ekonomickej neslobody a prítomnosti ekonomickej moci. Táto moc bola podl'a Polanyiho aj v tradičných spoločenstvách dôvodom tak alebo inak nedokonalej ochrany slabých. No to, čo odlišuje tradičného človeka od nakupujúceho a na trhu sa predávajúceho indivídua, je ako to zopakuje po ňom Stiglitz -, „že nikdy nepostrádal zárobok a zamestnanie“ (Stiglitz 2001, 6).

Vo vzt’ahu $\mathrm{k}$ tomu historickému špecifiku v čase kríz v modernej priemyselnej epoche „indivíduá nezmôžu takmer nič; [...] sú zmietané silami mimo ich kontroly“ (tamže). Jedna zo zásadných výčitiek Polnayiho sa týka neschopnosti „liberálov“ uznat' ekonomicky nedobrovol’nú nezamestnanost', nepokladat' ju za výsledok vysokými mzdami „prejedenej“ budúcnosti.

\section{Princíp dobrovol'nosti}

To, čo legitimizuje prirodzený poriadok trhu, je princíp dobrovol’ne uzatvorenej pracovnej zmluvy a na rovnakom princípe negatívnej slobody založenej možnosti jej vypovedania. Polanyi a Tugendhat, každý z inej perspektívy, kritizujú moderný koncept sociálneho kontraktu, no súčasne podrobujú kritike aj podmienku možnosti tohto kritéria „,nezasahovania“ do trhu práce na základe nominalistického uchopenia a) motívov konania a b) sociálnej reality.

Podla Polanyiho „civilizačný zrod laissez-faire“ znamenal vznik historicky unikátneho a nového faktora „ekonomickej motivácie“ konania vo vlastnom záujme ako výrazu l'udskej prirodzenosti. Polanyi vníma tento utilitaristický pohl'ad na človeka v optike trhovej ekonomiky v duchu aplikácie libertariánskeho kréda na sféru konania - ako oddel'ovanie pôvodne sociálnych motívov konania od jeho len ekonomicky mo- 
tivujúcich determinantov - „hladu“ a „zisku“. Za ideových otcov tohto konceptu Polanyi uvádza autora populačnej teórie Thomasa Malthusa a jeho priameho prechodu Josepha Townsenda. ${ }^{8}$

„Hlad“" a „túžba po zisku“ nie sú samy osebe „ekonomickým faktormi,“ podobne ako ich dejinne nadobudnutý vplyv nemôže byt' vysvetl'ovaný na deterministický spôsob prirodzenej gravitácie podl'a prírodného zákona. „Žiaden l’udský pud per se nie je ekonomickým motívom... Ked' hladuje jednotlivec, zd’aleka to ešte neznemená, že to vedie k určitej činnosti““ (Polanyi 1979, 134). Na to, aby sa pudovo založený hlad a rovnako silná túžba po zisku stali produkčnými faktormi a motívmi ekonomicky podmieneného správania, museli by byt' súčastou zmeny v rámci kolektívne organizovanej trhovej spoločnosti. Pretože ,produkcia nie je individuálna, ale kolektívna záležitost"“ (tamže). V tom istom texte s názvom Naše obsolétne trhovo-hospodárske myslenie (1947) Polanyi potom výstižne poukazuje na okolnost', ktorou „hlad“" (sprostredkovane „túžba po zisku“) mohli získat’ dejinný vplyv.

To, čo umožnilo osamostatnenie inštitúcie volného trhu od „zvyšku“ spoločnosti, teda byt' ekonomickým faktorom, „byt' jediným režisérom“ l'udských osudov, nebolo primárne prirodzene limitované množstvo potravy, ale legislativne umožnená strata alternatívneho živobytia pre novovzniknutú pauperizovanú väčšinu v prepojení s prechodom na továrenskú výrobu s kvalitatívne novými možnost’ami bohatnutia investorov. Zásadná kritika Hayekovho pojmu slobody Tugendhatovým odkazom na neosobne založenú ekonomickú neslobodu ako životnú situáciu ,nemat' prakticky na výber“, čiže nemat' alternatívne zdroje živobytia, sa teda priamo týka aj Polanyiho opisu podmienky možnosti vzniku konkurencieschopného trhu práce - zabezpečenia živobytia predajom vlastnej práce. ${ }^{9}$

\footnotetext{
${ }^{8}$ Ten vo svojej práci Pozorovania o Chudobínskom zákone (1786) navrhol zrušit' Chudobínsky zákon požiadavkou, aby si chudobní sami na trhu hl’adali prácu za akúkol'vek mzdu. Viedli ho tomu obavy z narušenia prirodzenej rovnováhy medzi ,počtom obyvatel’stva“ a „,ostatkom potravy“ v dôsledku záhal'ky a stúpajúcej pôrodnej krivky na základe asociálneho Chudobínskeho zákona. No až Malthus vysvetlil, prečo ,hlad“, a nie zákon, musí byt' podmienkou rovnováhy s odkazom na „sexualitu“: princíp „hladu“v dôsledku nedostatku potravín z premnoženia vedie k vojnám a chorobám, ktoré prirodzene regulujú rovnováhu (pozri Polanyi 1978, 200 - 201; 1944, 127).

${ }^{9}$ Trh práce vo Vel'kej Británii vznikol až po zrušení Zákona o osídlení (1795) a po „neslávne známej“ reforme Zákona o právach chudobným (1834), ktorou sa rušila dovtedy paternalistická podpora chudobných. „Chudobným zostal na výber len hlad alebo práca. Týmto spôsobom bol vytvorený národný a konkurencieschopný trh práce“ (Polanyi 1979, 138). Ani trh práce teda nevznikol „prirodzene“, ale ako súčast' masívnych vládnych opatrení. O desat' rokov nasledoval Bankový zákon (1844) - „výdaj peňazí bol vzatý z rúk vlády“ (tamže), bez ohl’adu na dôsledky na stupeň nezamestnanosti, ktoré s tým boli spojené . A nakoniec bola prevedená reforma Zákona o pôde a v roku 1846 zrušený Zákon o obilí, čím sa umožnila komercializácia pôdy a medzinárodný obchod s obilím: „Verilo sa, že ak by mohlo do Británie prúdit’ obilie z celého sveta, jej továrne by mohli po celom svete predávat' lacnejšie“" (Polanyi 1944, 140).
} 


\section{Spoločenská zmluva ako vôl’a $k$ moci}

Práve táto redukcia slobody na individuálne konanie vo vlastnom záujme je predpokladom teórie spoločenskej zmluvy, podla ktorej je moderný trhový poriadok výsledkom slobodných rozhodnutí, ktoré medzi sebou uzatvárajú dobrovol’ne kooperujúce indivíduá. Polanyi by sa určite zhodol s Tugendhatom v jeho kritike kontraktualistického konceptu spoločenskej zmluvy ako potvrdenia asymetrickej vôle k moci - „morálky silných“ (Tugenhat 1993). Táto kritika zahŕňa dva predpoklady, ktoré sú vlastné Polanyiho opisu vzniku vol'ného trhu: 1) Tugendhatovo odmietnutie prirodzeného stavu ako východiska spoločenskej zmluvy a z tohto odmietnutia vyplývajúce rozšírenie pojmu moci a neslobody z politickej na ekonomickú sféru; a 2) normatívne založenú kritiku spoločenskej zmluvy, založenú na premise maximalizácie vlastných záujmov (princíp čierneho pasažiera).

Čo sa týka prvej roviny, ako sme už ukázali na inom mieste, ${ }^{10}$ Tugendhat kriticky vymedzuje tradíciu stotožňovania ochrany súkromného vlastníctva s ochranou slobody jednotlivca u Johna Locka a Roberta Nozika (porov. Tugendhat 1993, 312 - 336). Primát „práva vlastnit“" v kombinácii s konceptom prirodzených - predspoločenských práv naozaj umožňuje zredukovat' problém l’udskej slobody na vzt'ahy medzi jednotlivými l'ud’mi, ked’že toto právo a ostatné práva už medzi nimi platia pred reálnou spoločnost’ou - a nezávisle od nej. Ked’že tieto práva platia ako „neodňatel'né“ a „nescudzitel'né“" sú človeku prepožičané z vyššej - predspoločenskej - moci, každá vláda (ako „nočný strážnik“) má len negatívne povinnosti a musí postupovat’ tak ,aby [len] chránila tieto práva“. ${ }^{11} \mathrm{Z}$ libertariánskeho konceptu prirodzeného práva vlastnit’ ako garanta ludskej slobody však vypadávajú pozitívne l'udské práva aj z iného ako „prirodzeného“ dôvodu.

Druhým klúčovým bodom, ktorý prepája Polanyiho kritiku „prirodzeného“ poriadku vol’ného trhu s Tugendhatovým filozofickým konceptom, je kritika kontraktualizmu. V Tugendhatovom vymedzení ide o spoločenskú kooperáciu, založenú na maxime vlastného záujmu. Spoločenská zmluva platí, lebo spolupráca, a nie vojna všetkých proti všetkým, je výhodná pre každého. Podl'a známeho princípu čierneho pasažiera, o ktorý sa Tugendhat vo svojej kritike opiera, z princípu vzájomne výhodnej spolupráce musí vyplývat' jej opak. Pokial' je môj záujem mierou všetkých vecí, v princípe musím spoločenskú dohodu porušit', ak je to v môj prospech - a nik ma pri tom nevidí. Kritickým problémom kontraktualizmu je jeho účelová racionalita: „Proti kontraktualizmu bolo preto vždy namietané, že z neho nemôže vzíst’ žiadna skutočná morálka, len výmenný obchod“ (Tugendhat 1995, 374). Tugendhat pod morálkou ne-

${ }^{10}$ Porov. Muránsky $(2019,13-36)$.

${ }^{11}$ Porov. Tugendhat $(2010,266)$. 
rozumie primárne vzt’ahy medzi jednotlivcami, ale politickú morálku pravidiel, ktorými sa určuje legitimita štátu. „Skutočná morálka“ musí byt' založená na zohl’adňovaní záujmov všetkých členov spoločenstva.

Hlavný motív tohto egalitaristického konceptu je súčasne základným problémom a kritickým nedostatkom kontraktualizmu. Tugendhat ho pomenuje „zlým mýtom“ a má tým na mysli opät’ hypotetický „,prirodzený stav“, ktorý vychádza z predpokladu výlučne „dospelých l’udí, ktorí sa už vedia o seba postarat““ (Tugendhat 1993, 358). V takejto spoločnosti „,práceschopných mužov“, určite existuje jej čast', ktorá nie je odkázaná na solidaritu ostatných. Sama sa dokáže postarat' o seba, svoje deti a starých alebo zdravotne znevýhodnených l'udí. No podl'a Tugendhata je to tá menšia čast' spoločnosti. Tej väčšinovej časti k tomu chýbajú sociálne dostupné „zdroje“ a „schopnosti“ a navyše často aj „príležitosti““ ich uplatnit' - tri zložky konceptu pozitívnej slobody. Adresátom z toho plynúcich ,pozitívnych“ sociálnych a ekonomických práv môže byt' len pozemská vláda, nie však prirodzene izolovaný jedinec.

Podl'a Polanyiho a Tugehdhata nemožno akceptovat' fiktívnost' reality, po prvé, v ktorej sa každý už vie o seba postarat', lebo už v prirodzenom stave je vlastníkom zdrojov na samostatné živobytie alebo vd’aka neobmedzenosti zdrojov sa ním môže stat'. ${ }^{12} \mathrm{~V}$ dejinnej realite takýto svet neobsadených zdrojov a už nejako nadobudnutých schopností pre samostatný život nikdy pre väčšinu spoločnosti neexistoval. V tomto duchu možno modifikovat' slávny termín Hannah Arendtovej o „práve mat' práva“ (porov. Pohlmann, Lohmann 2012, 94 - 99) a modifikovat' ho na „právo uskutočňovat' svoje práva“. K nemu potom patrí „,zaistenie minimálneho pozitívneho slobodného priestoru", v ktorom by sa jeho nositelia vedeli postarat' o seba a svojich blízkych. Takéto zaistenie „sa javí rovnako základným právom ako právo na telesnú nedotknutel'nost' a niektoré negatívne práva“" (Tugendhat 1993, 360).

Po druhé, obaja myslitelia spochybňujú tiež základné libertariánske krédo trickle down economy, ${ }^{13}$ podl'a ktorého sú privátne podnikanie a vol'ný trh nevyhnutnou podmienkou zlepšenia postavenia všetkých, aj sociálne slabých v spoločnosti. V realite Vel'kej depresie, ale aj v Grécku po roku 2008, platí Polanyiho protinávrh: „liberálna idea slobod“ sa mení „[...] na fikciu. To znamená na plnú slobodu pre tých, ktorých príjem, vol'ný čas a bezpečnost' jej zväčšovanie vôbec nepotrebujú, a na obyčajný ždibec slobôd pre l'udí, ktorí sa márne pokúšajú využit' svoje demokratické práva, aby sa chránili pred silou vlastníkov majetku (Polanyi 1944, 254). Trickle down princíp sa netýka len vzt'ahov medzi l'ud'mi, ale primárne sa zakladá na vzt'ahoch medzi prosperujúcimi a zaostávajúcimi štátmi..

${ }^{12}$ Porov. Nozik $(1999,179)$.

${ }^{13}$ Porov. (tamže 1999, 177). 


\section{Medzinárodné spoločenstvo vol'ného trhu}

Je to práve rozšírenie libertariánskeho kréda o vol'nom trhu do globálneho priestoru, ${ }^{14}$ ktoré podl'a sebapochopenia jeho aktérov tvorí jadro toho projektu (porov. Mises 1927, 93 - 98). Až ked’ sa firmám či indivíduám poskytne nadnárodný priestor na sledovanie vlastných ekonomických záujmov, vznikne priestor - podl'a tohto kréda - pre celosvetovú prosperitu a mierové medzinárodné spoločenstvo. Polanyi vo svojich analýzach mechanizmov fungovania svetových hospodárskych kríz ukázal, že tí, ktorí uverili takejto vízii obchodne založeného mierového spoločenstva, si veci značne zjednodušili, ked' ekonomický libertarianizmus chceli zbavit' zodpovednosti za najväššie humanitárne katastrofy dvadsiateho storočia. Jeho analýzy vzniku druhej svetovej vojny ukázali, že to nebol „genetický kód národov“, čo umožnil nástup fašizmu, ale zlyhanie zlatého štandardu a jeho neúnosných sociálnych nákladov (Polanyi 1944, 255). ${ }^{15} \mathrm{~V}$ dejinnej realite sa náklady na udržanie rovnováhy zlatým štandardom asymetricky prenášali na zadlžené krajiny, a to sociálne deštrukčným spôsobom. ${ }^{16}$

Ideál dokonalého harmonického spoločenstva, ktorým chcel Berlin vyjadrit' podstatu totalitarizmu v myslení nemeckých idealistov a Marxa, reprezentuje v Polanyiho interpretácii práve stotožnenie slobody s ideou samoregulujúceho sa medzinárodného trhu. A to z jedného rozhodujúceho dôvodu: takýto systém medzinárodných vzt’ahov, ktorý funguje na báze negatívnej slobody „nezasahovania“, sa kladie ako opozitum každej kolektívne organizovanej moci a násiliu. No adresátom uplatňovania pozitívnych l'udských práv je však vláda, a teda spoločenstvo občanov organizované v štáte.

Problémom libertariánskeho konceptu nie je upozornenie na principiálnu zneužitel'nost' štátnej moci (o nej sú prvé deklarácie l'udských práv), ale fundamentálne sto-

\footnotetext{
${ }^{14}$ Polanyiho analýza pádu zlatého štandardu pred prvou a druhou svetovou vojnou je dnes najvplyvnejším segmentom jeho myslenia. Okrem Josepha Stiglitza sa po finančnej kríze 2008 o oživenie záujmu o Polanyiho dielo postaral sociológ Wolfgang Streeck v knihe Kupovanie času (2013). Základnú tézu odd’alovaní krízy kupovaním dlhov štátov Streeck preberá z Polanyiho článku Mechanizmus svetovej hospodárskej krízy (Polanyi 1979, 63 - 81). O vplyve Streeckovej práce svedčí jeho polemika s Jürgenom Habermasom o budúcnosti Európy, vydaná pod titulom Vo víre technokracie (2013). K tomu bližšie Muránsky (2014).

${ }^{15}$ Realita tridsiatich miliónov nezamestnaných a deflácia umožnili univerzálny nástup fašizmu v Európe ako „realistickú“ reakciu vzhl'adom na sociálny stav v čase ,jeho liberálneho popierania“ - aj za cenu ,popretia idey slobody vôbec“ (Polanyi 1944, 255). Polanyi tu naráža na nemožnost' prijat’ zodpovednost' za ,,všeobecnú nezamestnanost“" liberálnym princípom negatívnej slobody a následne za jej nominalistické vysvetl'ovanie.

${ }^{16}$ Relevantnost' Polanyiho interpretácie potvrdzujú mnohé texty o vzt'ahu demokracie a ekonomiky, ktoré po roku 2008 napísali autori ako Joseph Stiglitz, Coulin Crunch alebo Jürgen Habermas. V jednom z nich sa Habermas vyjadril o socializácii strát bankového sektora (tzv. záchranné padáky), ktoré zaplatili dane „vlád a občanov“, ako o „najväčšom povojnovom normatívnom škandále“. Ním sa „občianska demokracia“ zmenila na jej opak ,trhovo-konformnú fasádovú demokraciu“ (Habermas 2013, 36). V tomto vymedzení je nepriatel’om slobody už aj „neviditel’ná moc trhov“ (tamže).
} 
tožnenie štátnej - kolektívne organizovanej - moci ako nepriatel'a slobody na vnútornom a globálnom trhu. Pre Polanyiho bol však aj laissez-faire „naplánovaný“ vládou, a čo je v danej súvislosti rozhodujúce, „obrana spoločnosti“" pred jeho sebadeštruktívnymi dôsledkami sa diala a deje vždy kolektívne - počnúc l'udským právom na slobodné združovanie až po vládnou exekutívou stanovovanú výšky minimálnej mzdy.

Tugendhat je v nezastupitel'nej úlohe štátu pri presadzovaní sociálnych práv tiež jednoznačný. Navyše je presvedčený, že každé právo, aj právo na vlastníctvo, je možné len ako štátom intersubjektívne garantovaný a vymáhatel'ný vzt'ah. Preto pod ,štátom“ netreba rozumiet' nepriatel’a slobody, ale „inštitúciu, ktorú si občania vytvorili sami z dôvodu, aby si tieto práva vzájomne garantovali“" (Tugendhat 1993, 352). Rozsah takýchto štátom garantovaných práv sa nedá vymedzit predstavou dospelých izolovaných jedincov, ktorí sa už vedia o seba postarat'. Naopak, to, čo sa prirodzene zabezpečuje det'om, lebo sa nedokážu o seba postarat' (výživa, bývanie, zdravie), treba rozšírit' o podobné práva pre ostatných členov spoločnosti, o ktorých sa nemá kto postarat'. „Žiadne indivíduum by nikdy neprežilo, ak by sa nenarodilo do spoločnosti““ (tamže, 358). To platí pre jednotlivcov, ktorí sú dnes deti a raz budú chorí a starí, a vice versa pre dnešných starých a chorých, ktorí už boli det'mi.

\section{Na záver}

V našej štúdii sme vyšli zo spoločných motívov Polanyiho a Tugedhatovej antropológie, založených na uznaní konfliktného vzt’ahu medzi „právom vlastnit““ a „právom na život“", a zo zdôraznenia nedelitel'ného konceptu občianskych a sociálnych práv človeka ako odpovede naň. Poukázaním na „konečnost' zmyslu“ a z neho plynúceho nároku na spoločenskú zodpovednost' ,sme zároveň upozornili na dva normatívne predpoklady výpadku pozitívnej slobody a sociálnych práv z libertariánskej agendy. Po prvé, jej nominalistické uchopenie reality slobodne predávajúcich a vyrábajúcich jedincov (Berlin), ktoré Polanyi napáda svojou tézou „o dvojitom pohybe spoločnosti“ a Tugendhat spochybňuje svojou kritikou legitimizácie týchto vzt’ahov prostredníctvom jeho výkladu princípu dobrovol'nej zmluvy ako prejavu vôle k (ekonomickej) moci. Druhým predpokladom libertarianizmu je oddel’ovanie vol'ného trhu od zvyšku spoločnosti na základe jeho vymedzenia ako prirodzeného poriadku, a nie výsledku ludskej kooperácie činnosti. Tugendhatova kritika prirodzeného spoločenstva ako fiktívneho sveta len dospelých mužov, ktorí sa už vedia o seba postarat', a súčasne v tejto ilúzii predspoločenskej sebestačnosti zdrojov podmienka možnosti len negatívnej slobody - a Polanyiho zásadný odkaz na humanitárne katastrofy a neslobody z dôsledku zlyhávania zlatého štandardu ako údajného prirodzeného regulátora vzt’ahov medzi štátmi a ich občanmi -, potvrdzujú aktuálnost’ oboch myšlienkových výkonov a filozofickú relevantnost' egalitárneho ukotvenia sociálnych práv do d’alšej diskusie. 


\section{Literatúra}

BERLIN. I. (1997): Dva pojmy slobody. In: Kiss. J. (ed.): Současná politická filozofie. Praha: Oikoymenh, $47-101$.

HABERMAS, J. (2013): Demokratie oder Kapitalismus? In: Im Sog der Technokratie. Frankfurt am Main: Suhrkamp.

HUMPREYS, C. S. (1979): Geschichte, Volkswirtschaft und Antropologie:. In: Ökonomie und Gesellschaft. Suhrkamp, $7-62$.

MISES, L (1927): Liberalizmus. Jena: Verlag von gustav Fischer.

NOZIK, R. (1973): Distributive justice. In: Anarchy, State and Utopia. Blackwell 1973, 149 - 182.

POLANYI, K (1979): Unseres obsoletes marktwirschafliches Denken. In: Ökonomie und Gesellschaft. Frankfurt am Main: Suhrkamp, 129 - 149.

POLANYI, K (1978): Das Wesen des Faschismus. In: Ökonomie und Gesellschaft. Frankfurt am Main: Suhrkamp, $91-128$

POLANYI, K. (1944): Velká transformace. Brno: CDK 2006.

POLANYI-LEVITT, K: (1990) The Life and Work of Karl Polanyi. Montreal: Black Rose Books, 1990.

SEDOVÁ, T. (2018): Jánusovská tvár l'udských práv: medzi l'udskou dôstojnost'ou a právom mat' práva. Filozofia, 73 (4), 318 - 328.

SMREKOVÁ, D. (2010): Čo znamená prevziat' zodpovednost? K pojmu imputácie v súčasnej etike. Filozofia, 65 (9), 893 - 906.

THOMASBERGER, C. (2008): Gesellschaftliche Freiheit und Marktordnung In: Hieke, H. (ed): Kapitalismus Kritische Betrachtungen und Reformansätze. Marburg: Metropolis Verlag.

TUGENDHAT, E. (1979): Die Hilflosigkeit der Philosophen angesichts der moralischen Schwierigkeiten von heute. In: Tugendhat, E. (1992) (ed.): Philosophische Aufsätze. Frankfur am Maint: Suhrkamp, $371-385$.

TUGENDHAT, E. (1993): Vorlesungen über Ethik. Frankfurt am Main: Suhrkamp.

TUGENDHAT, E. (2010): Antropologie statt Metaphysik. München: Verlag C. H. Beck.

Táto práca vznikla v rámci projektu VEGA 2/0049/20 K idei l'udských práv-koncepty, problémy, perspektivy.

Martin Muránsky

Filozofický ústav SAV

Klemensova 1

81364 Bratislava 1

Slovenská republika

e-mail: muransky.ma@gmail.com

ORCID ID: https://orcid.org/0000-0002-1986-0460 